During DBcAMP $(0.5 \mathrm{mg} / \mathrm{kg} / \mathrm{min})$ infusion, urine flow of both kidneys increased significantly (Table 1). An average increase of the infused kidney was $136 \%$ and that of the noninfused kidney $10 \%$. Sodium, potassium and osmolar excretion were also promoted, while no significant changes were observed in the concentration of serum sodium and potassium or serum osmolarity. Free water reabsorption of the infused kidney was enhanced, but not in the noninfused kidney. Glomerular filtration rate (GFR) and renal plasma flow (RPF) increased slightly, but the systemic blood pressure remained constant. After cessation of drug infusion, all variables easily returned to their preinfusion levels.

During cAMP $(0.5 \mathrm{mg} / \mathrm{kg} / \mathrm{min})$ infusion, a urine flow decreased by about $35 \%$ in the infused kidney and about $15 \%$ in the noninfused kidney. Sodium, potassium, osmolar excretion and free water reabsorption decreased simultaneously. GFR and RPF were reduced in the absence of changes in systemic blood pressure. Following drug infusion, all variables except for free water reabsorption returned to their preinfusion levels.

It seems that the antidiuretic effect of cAMP is due to its hemodynamic actions; decrease in RPF and GFR. But, DBcAMP decreases neither RPF nor GFR. It produces a marked diuresis accompanied by an increase in sodium, potassium and osmolar excretion in a greater degree in the infused kidney than in the noninfused kidney. The present results suggest that the diuretic action of DBcAMP is not through its hemodynamic action but its direct action on tubular cells.

The mechanism of action of DBcAMP is underway.

\title{
REFERENCES
}

1) Sutherland, E.W. and Rali., T.W.: Pharmac. Rev. 12, 265 (1960); 2) Orloff, J. and Handler, J.S.: J. clin. Invest. 41, 702 (1962); 3) Handler, J.S., Butcher, R.W., Sutherland, E.W. and Orloff, J.: J. biol. Chem. 240, 4524 (1965); 4) Posternak, T., Sutherland, E.W. and Henion, W.F.: Biochim. biophys. Acta 65, 558 (1962)

\section{MICROPERFUSION EXPERIMENTS IN GOLLECTING DUGTS OF THE ISOLATED RAT RENAL MEDULLA IN VITRO}

\author{
MASAO TADOKORO, ISAO YAMAGUCHI, MAKOTO TERAOKA \\ AND FUMINORI SAKAI \\ Department of Pharmacology, Faculty of Medicine, University of Tokyo, Bunkyo-ku, Tokvo
}

Received for publication February 26, 1968

It has been reported that vasopressin increases the water permeability of isolated cortical collecting tubules (1), but the effect of it on medullary collecting ducts has not yet been proved directly. The kidney of adult rat weighing $200-300 \mathrm{~g}$ was excised and its whole medulla was isolated carefully so as not to injure the natural papillary surface. The isolated medulla was fixed in the organ bath filled with the bath fluid, which was oxygenated with $100 \% \mathrm{O}_{2}$ and replaced about every 20 minutes. After about 120 minute incubation, a collecting duct on the surface was punctured with a perfusion glass-micropipette filled with colored perfusion fluid. The pipette was connected to a microperfusion pump and perfused constantly at the rate of $20 \mathrm{nl} / \mathrm{min}$. The composition of the solutions was as follows :

田所 昌夫・山口 勲・寺岡 詝・酒井 文徳

Supported by U.S. NIH grant AMO9742 
Bath fluid: $\mathrm{NaCl} 238.35 \mathrm{~mm}, \mathrm{KCl} 8.0 \mathrm{~mm}, \mathrm{CaCl}_{2} 1.8 \mathrm{~mm}, \mathrm{MgCl}_{2} 0.525 \mathrm{~mm}$, Urea $343.0 \mathrm{~mm}$, Glucose $7.7 \mathrm{~mm}, \mathrm{NaHCO}_{3} 0.5 \mathrm{~mm}$, Phosphate buffer (pH 7.2) $2 \mathrm{~mm}$.

Perfusate: identical to the bath fluid except that the concentration of $\mathrm{NaCl}$ was $100 \mathrm{~mm}$ and that no glucose was added. The perfusate was colored with $0.25 \%$ light green and inulin $-{ }^{14} \mathrm{COOH}$ was added in a concentration of $50 \mu \mathrm{c} / \mathrm{ml}$.

The perfused fluid was collected with a second sharpened glass-micropipette at a site about $2400 \mu$ distal to the perfusion pipette with or without addition of vasopressin to the outside bathing medium $(2 \mathrm{mU} / \mathrm{ml})$. The osmolality, $\mathrm{Na}$ concentration and inulin $-{ }^{14} \mathrm{C}$ radioactivity of the collected fluids and the perfusate were measured, using Ramsay's microcryoscopic technique, an Erma ultramicroflame photometry and an Aloka gas flow counter for each determination. All experiments were performed at room temperature $\left(21-24^{\circ} \mathrm{C}\right)$.

TABLE 1. Calculated ratio (collected fluid/perfusate) of inulin concentration, osmolality and $\mathrm{Na}$ concentration in the absence and in the presence of vasopressin.

\begin{tabular}{cccc}
\hline & Inulin ratio & Osmolal ratio & Na ratio \\
\hline ADH $(-)$ & $\begin{array}{c}1.048 \pm 0.0109 \\
(\mathrm{n}=11)\end{array}$ & $\begin{array}{c}1.071 \pm 0.0104 \\
(\mathrm{n}=11)\end{array}$ & $\begin{array}{c}1.166 \pm 0.0369 \\
(\mathrm{n}=11)\end{array}$ \\
$\mathrm{ADH}(+)$ & $\begin{array}{c}1.524 \pm 0.0257 \\
(\mathrm{n}=12)\end{array}$ & $\begin{array}{c}1.335 \pm 0.0215 \\
(\mathrm{n}=12)\end{array}$ & $\begin{array}{c}1.688 \pm 0.0243 \\
(\mathrm{n}=11)\end{array}$ \\
\hline
\end{tabular}

Values are averages with standard errors. All the ratios are significantly higher in the presence of vasopressin than in the absence of it $(\mathbf{P}<0.001)$. The differences between the inulin ratio and the $\mathrm{Na}$ ratio and those between the osmolal ratio and the $\mathrm{Na}$ ratio are significant at the level of $1 \%$ and $5 \%$, respectively, without vasopressin. The three ratios in the presence of it are significantly different one another at $0.1 \%$ level.

Data of the calculated ratio, collected fluid/perfusate, of the osmolality, Na concentration and inulin${ }^{14} \mathrm{C}$ radioactivity in each case of the experimental conditions were summarized in Table 1 . All the ratios were significantly higher in the presence of vasopressin in the outside bathing medium than in the absence of it. $(\mathrm{P}<0.001)$ When vasopressin present, the $\mathrm{Na}$ ratio was highest and the inulin ratio was higher than the osmolal ratio implying that $\mathrm{Na}$ entered and some solute escaped from the medullary collecting ducts. As the latter no other solute than urea, if not all, could be assumed under the experimental conditions.

These results indicate that net outward movements of urea as well as water are increased by vasopressin and suggest moreover that similar preparations of other renal tissues might be adaptable to the studies of tubular segments locating deep in renal tissues.

\section{REFERENCE}

1) Grantham, J.J. and Burg, M.B.: Am. J. Physiol. 211, 255 (1966) 